VOL. 2 NO. 2 JANUARI - JUNI 2018 e-ISSN: 2621-5306

VOL. III NO. 1 JANUARI - JUNI 2018 p-ISSN: 2541-5255

\title{
PENGUNGKAPAN CSR PERBANGKAN SYARIAH SEBAGAI KEBUTUHAN INFORMASI STAKEHOLDER
}

\author{
${ }^{1}$ Reztu Rinovian; ${ }^{2}$ Abin Suarsa \\ ${ }^{1 ; 2}$ Sekolah Tinggi Ilmu Ekonomi Muhammadiyah Bandung \\ 2abinsuarsa@stiemb.ac.id
}

\begin{abstract}
ABSTRAK
Penelitian ini bertujuan untuk menganalisis pengungkapan tanggung jawab sosial perusahaan oleh Bank Syariah Mandiri dan Bank Syariah Bukopin Syariah berdasarkan konsep shariah enterprise theory. Penelitian ini dilakukan dengan menganalisis bagaimana Bank Syariah Mandiri dan Bank Syariah Bukopin mengungkapkan tanggung jawab sosial perusahaannya melalui informasi yang disajikan dalam laporan tahunan didasarkan pada item-item pengungkapan tanggung jawab sosial berdasarkan syariah enterprise theory. Penelitian ini menggunakan metode kualitatif dengan metode penelitian studi kasus dimana dalam analisisnya menggunakan analisis isi.Data yang digunakan dalam penelitian ini adalah data sekunder berupa dokumen tertulis yakni laporan tahunan milik Bank Syariah Mandiri dan Bank Syariah Bukopin yang diperoleh dari situs resmi Bank Syariah Mandiri dan Bank Syariah Bukopin.Penelitian ini bersifat deskriptif interpretatif dengan membahas permasalahan dengan uraian - uraian yang jelas berdasarkan kemampuan pemahaman peneliti untuk mengungkapkan maksud informasi yang disajikan dalam laporan tahunan Bank Syariah Mandiri. Penelitian ini menunjukan bahwa pengungkapan tanggung jawab sosial dan Bank Syariah Mandiri dan Bank Syariah Bukopin masih sangat terbatas, serta masih jauh dari sesuai dengan syariah enterprise theory
\end{abstract}

Kata kunci: Pengungkapan Laporan Islamic CSR sebagai kebutuhan informasi stakeholder

\section{ABSTRACT}

This research aims to analyze the disclosure of corporate social responsibility by Bank Syariah Mandiri dan Bank Syariah Bukopin based on shariah enterprise theory. This research wasconducted by analyzing how the Bank Syariah Mandiri dan Bank Syariah Bukopin disclose corporate social responsibility through the information presented in the annual report are based on the items disclosure of social responsibility based on sharia enterprise theory. This research uses a qualitative method with case study method in which the analysis using content analysis. The data used in this research is secondary data in the form of a written document that is the annual report of Bank Syariah Mandiri dan Bank Syariah Bukopin obtained from the official website of Bank Syariah Mandiri dan Bank Syariah Bukopin. This research is descriptive interpretative 
to discuss problems with clear descriptions based on the ability of researchers to reveal the purpose of understanding the information presented in the annual report of Bank Syariah Mandiri dan Bank Syariah Bukopin. This research shows that social responsibility reporting Bank Syariah Mandiri dan Bank Syariah Bukopin still very limited, and is far from being in accordance with sharia enterprise theory.

Keyword :Disclosure report islamic CSR as Informasion for Stakeholder

\section{Pendahuluan}

Istilah CSR diperkenalkan pertama kali dalam tulisan Social Responsibility of the Businessman tahun 1953. CSR digagas Howard Rothmann Browen untuk mengeleminasi keresahan dunia bisnis. CSR adalah sebuah pendekatan dimana perusahaan mengintegrasikan kepedulian sosial dalam operasi bisnis mereka. CSR biasa dikatakan komitmen yang berkesinambungan dari kalangan bisnis, untuk berperilaku secara etis dan memberi kontribusi bagi perkembangan ekonomi, seraya meningkatkan kualitas kehidupan dari karyawan dan keluarganya, serta komunitas lokal dan masyarakat luas pada umumnya. (Lailatul khasanah, 2016:2).

Kendala yang masih banyak ditemukan di lapangan dalam pelaksanaan $C S R$ adalah masalah biaya, SDM yang kompeten, distribusi kegiatan serta penentuan target, bentuk kegiatan, masalah perizinan dan regulasi, kurangnya kemitraan, sosialisasi kegiatan, pemahaman mengenai pelaksanaan dan evaluasi di lapangan, dan masih banyak oknum yang melakukan pungutan liar di lapangan. (Maria Hudaibyah Azzahra:2016)

Perusahaan dituntut untuk memberikan informasi mengenai aktivitas sosialnya. Tanggung jawab sosial merupakan bentuk pengungkapan informasi sosial dan lingkungan hidup yang disebabkan kegiatan perusahaan yang dilaporkan secara sukarela oleh perusahaan. Sejauh ini dalam akuntansi,pusat perhatian perusahaan hanya terbatas kepada stockholders dan bondholders, yang secara langsung memberikan kontribusinya bagi perusahaan, sedangkan pihak lain sering diabaikan. (Ririn Irmadariyani, 2010:36).

Sehingga akuntansi konvensional sering kali dianggap tidak dapat mengakomodasi kepentingan masyarakat secara luas. Hal tersebut 
mendorong munculnya konsep akuntansi yang baru, yang disebut sebagai Akuntansi Pertanggungjawaban Sosial atau Corporate Social Responsibility. (Fitria dan Hartanti, 2010).

$$
\text { Kegiatan CSR semata-mata }
$$
merupakan komitmen perusahaan secara sukarela untuk turut meningkatkan kesejahteraan komunitas dan bukan merupakan aktivitas bisnis yang diwajibkan oleh hukum dan perundangundangan seperti kewajiban untuk membayar pajak atau kepatuhan perusahaan terhadap undang - undang ketenagakerjaan. CSR memang sifatnya hanya voluntary perlu ditingkatkan menjadi CSR yang lebih bersifat mandatory.

$$
\text { Dengan demikian dapat }
$$
diharapkan bahwa kontribusi dunia usaha yang terstruktur dan sistematis dapat meningkatkan kesejahteraan masyarakat. CSR dipandang sebagai program memberdayakan masyarakat agar dapat Mandiri secara ekonomi atau setidaknya dapat memberikan dorongan agar terjadi perkembangan perekonomian di daerah tersebut. (Kotler dan Lee, 2005 ; Solihin, 2009 dalam lailatul khasanah, 2016:3).

Alasan perusahaan khususnya di bidang perbankan melakukan pelaporan sosial adalah karena adanya perubahan paradigma pertanggungjawaban, dari manajemen ke pemilik saham menjadi manajemen kepada seluruh stakeholder (Mulyanita,2009:7 dalam Syuhada Mansur,2012:108)

Sebagai wujud bukti kepedulian para ahli akuntansi di Indonesia dapat dilihat melalui Ikatan Akuntan Indonesia (IAI) dalam Pernyataan Standar Akuntansi Keuangan mengungkapkan tanggung jawab akan masalah lingkungan dan sosial.Di tanah air dimulainya CSR semakin menguat terutama setelah dinyatakan dengan tegas Undang - undang Corporate Social Responsibility (CSR).

Kini wacana mengenai tanggung jawab sosial perusahaan semakin umum dalam dunia bisnis. Kesadaran tentang pentingnya tanggung jawab sosial perusahaan mendorong entitas bisnis untuk melakukan pelaporan CSR. Banyak perusahaan di berbagai negara termasuk di Indonesia yang mengungkapkan praktik CSR tersebut, tak terkecuali industri perbankan nasional. Pengungkapan CSR dalam laporan tahunan perusahaan maupun sarana lainnya tidak hanya dilakukan oleh perbankan konvensional, tetapi juga dilakukan oleh perbankan syariah (Fitria 
dan Hartanti, 2010 dalam Dita Andraeny, 2014)

Larangan agama islam pada bunga (riba) mendorong adanya perbankan syariah yang memberikan pelayanan jasa perbankan kepada sebagian masyarakat yang tidak bisa dilayani oleh bank konvensional karena sistem bunga yang diterapkan.

Sebagian masyarakat muslim berkeyakinan bahwa sistem bank konvensional tidak sejalan dengan sistem syariah islam, oleh karena itu diharapkan dengan adanya bank-bank syariah dapat mengoptimalkan mobilitas dana masyarakat muslim (Lailatul khasanah, 2016)

Seiring dengan semakin berkembangnya pelaporan $C S R$ oleh bank syariah, maka semakin banyak pula penelitian yang dilakukan tentang sejauh mana tingkat pelaporan praktik CSR berdasarkan prinsip-prinsip syariah. Berikut adalah beberapa permasalahan penelitian terdahulu :

Zubairu (2012) menunjukkan bahwa praktik pengungkapan $C S R$ pada bank syariah masih minim, padahal bank tersebut mengklaim dirinya sebagai institusi yang beroperasi sesuai dengan prinsip Islam. Penelitian tersebut juga menyimpulkan bahwa praktik pengungkapan sosial bank Islam di Saudi Arabia tidak jauh berbeda dengan bank konvensional yang menjadi pesaingnya.

Etika Islam yang diharapkan menjadi pembeda utama pengungkapan bank Islam dan bank konvensional ternyata tidak tampak jelas dalam laporan tahunannya. Penelitian Mosaid dan Boutti (2012); dalam Dita Andraeny (2014) menunjukkan pula bahwa pengungkapan $C S R$ bank Islam masih kurang.

Bank syariah seharusnya memiliki dimensi spiritual yang lebih banyak. Dimensi spiritual ini tidak hanya menghendaki bisnis yang non riba, namun juga mampu memberikan kesejahteraan bagi masyarakat luas, terutama bagi golongan masyarakat ekonomi lemah (Meutia,2010 dalam Syuhada Manshur,2016).

Hal ini menurut (Othman dan Thani,2010 dalam Dita Andraeny,2014) menjadi indikasi kurangnya transparansi pengungkapan berdasarkan nilai-nilai Islam, padahal kenyataannya konsep akuntabilitas dalam Islam terkait dengan prinsip pengungkapan penuh (full disclosure). Perbankan syariah merupakan bidang yang menarik untuk dikaji, karena keberadaannya telah 
menyebar di seluruh dunia (Bedoui \& Mansour, 2013).

Menyimpulkan bahwa bank syariah yang diwajibkan membayar zakat telah melakukan pengungkapan sosial yang lebih baik dari bank syariah yang tidak diwajibkan membayar zakat. (Eka Cida,2016)

Coorporate Social Responsibility merupakan upaya perusahaan untuk meningkatkan kualitas hidup stakeholder. Stakeholder meliputi pernyataan yang melindungi kepentingan sosial, khususnya bagi pendirian atau pembangunan perusahaan baru.

Salah satu peraturan tersebut, seperti tercantum pada UU no 32 tahun 2009 tentang Perlindungan dan Pengelolaan Lingkungan hidup,pasal 22 ayat (1) Setiap usaha dan atau kegiatan yang berdampak penting terhadap lingkungan hidup wajib memiliki AMDAL. Berdasarkan pengalaman tersebut dapatlah dikatakan bahwa setiap perusahaan wajib meiliki tanggungjawab penuh terhadap lingkungan sosialnya.

Berdasarkan latar belakang masalah yang telah diuraikan maka tujuan peneltian untuk Pengungkapan Laporan CSR Sebagai Kebutuhan Informasi Stakeholder.

\section{Tinjauan Pustaka dan Fokus}

Penelitian

CSR Disclosure Perusahaan Menurut Islam

Dalam perspektif Islam (Sadeghzadeh, 1995; Baydoun dan Willett, 2000; Haniffa 2001; Lewis, 2001; Maali et al., 2003 dalam Farook dan Lanis, 2005:

"Kerangka umum tanggung jawab sosial dan akuntabilitas didasarkan pada nilainilai Islam yang tertanam dalam aturan hukum yang rinci yaitu Al-Qur'an dan ajaran Nabi Muhammad SAW. Berkaitan dengan hal ini, bank syariah yang melakukan kegiatan operasinya berdasarkan prinsip Islam, diharapkan untuk mengungkapkan informasi CSR yang relevan untuk memenuhi tanggung jawabnya sekaligus untuk memperoleh legitimasi bagi kelangsungan hidupnya “ Baydoun dan Willet (2000) dalam Othman dan Thani (2010) menyatakan bahwa dalam perspektif pelaporan perusahaan, terdapat dua prinsip penting terkait konsep akuntabilitas dalam Islam yaitu prinsip pengungkapan penuh (full disclosure) dan konsep akuntabilitas sosial :

“ Konsep akuntabilitas sosial menurut Islam terkait dengan prinsip full disclosure, yang mana penyedia laporan 
keuangan harus mengungkapkan segala sesuatuyang dinilai penting bagi stakeholder muslim. Sementara itu, konsep full disclosure berkaitan dengan konsep akuntabilitas. Eka cida Maret (2016)"

Dengan demikian, tujuan utama pelaporan sosial berbasis Islam ( Social Reporting) adalah untuk menunjukkan apakah suatu organisasi telah menjalankan prinsip-prinsip Islam, menunjukkan bagaimana operasi organisasi berpengaruh terhadap kesejahteraan masyarakat, serta untuk membantu masyarakat muslim menjalankan ibadahnya (Maali, et al 2006).

Konsep CSR dalam perspektif Islam lebih menjurus kepada pendekatan rohani (Norajilah:2011).

"Pandangan bersifat rohani adalah berdasarkan dari ajaran AlQuran dan Sunnah. Ide mengenai tanggung jawab sosial ini terkandung dalam ikatan kerohanian (religious bond). Ikatan kerohanian ini mengambarkan komitmen terhadap standar moral dan juga norma-norma sosial dengan berasaskan kepada Syariah.

Ini karena dalam Islam matmalat yang ingin dicapai bukan tertumpu kepada keperluan material saja, tetapi merangkumi konsep kesejahteraan hidup manusia yang menekankan konsep persaudaraan dan keadilan sosioekonomi, dan spiritual bagi setiap insan (Gillian rice: 1999).

$$
\text { Menurut Meutia terdapat }
$$
beberapa prinsip yang sebetulnya menggambarkan adanya hubungan antara manusia dan penciptanya, yaitu Allah SWT (Meutia: 2010).

"Prinsip-prinsip ini adalah berbagi dengan adil, rahmatan lil alamin (rahmat bagi seluruh alam), dan maslaha (kepentingan masyarakat). Menurut AlGhazali, prinsip-prinsip ini sebetulnya mempunyai kaitan yang kuat dengan tujuan ekonomi Syariah yang mengedepankan kepentingan masyarakat banyak" (Chapra, M Umer: 2007)

Muhammad Yasir Yusuf (2010), melakukan penelitian tentang bagaimana bentuk kebijakan yang seharusnya dilaksanakan oleh perbankan syariah dalam menjadikan CSR bermanfaat untuk menciptakan pemerataan kesejahteraan ekonomi masyarakat.

Hasil dari penelitian ini adalah penggunanan Maslahah dan Maqasid Syariah dalam penentu an kebijakan pelaksanaan CSR dapat membantu pengelolah bank syariah untuk 
menyelesaikan pilihan-pilihan rumit, konflik kepentingan antara Stakeholders dan benturan-benturan dalam pelaksanaan program $C S R$.

Berdasarkan pendapat Gambling dan Karim (1984) dalam Harahap (2003) dikemukakan bahwa:

"Dari sistem nilai Islami akan lahir sistem ekonomi dan sistem akuntansi Islam. Hal ini dikarenakan bahwa Islam adalah sistem nilai terpadu yang berasal dari Allah yang mutlak dan benar serta didesain sebagai suatu sistem terpadu bukan saja dikhususkan bidang tertentu, tetapi juga lengkap terintegrasi dengan kebutuhan dunia dan akhirat."

Dalam akuntansi Islam juga dijelaskan bagaimana mengalokasikan sumber kekayaan yang ada secara adil sesuai syari'ah. Bukan hanya mencatat transaksi perusahaan saja (Harahap, 2003), namun akuntansi Islam juga harus ikut serta menegakkan syariat Islam di berbagai aspek. Hameed (2008) mengemukakan bahwa tujuan dari akuntansi Islam adalah untuk mencapai al-falaah (kesejahteraan dunia dan akhirat).

Dalam merumuskan kerangka social reporting dalam perspektif Islam harus berlandaskan pada tiga dimensi (Haniffa, 2002) :
"Ketiga dimensi terssebut yakni, mencari ridho Allah; memberikan keuntungan kepada masyarakat; mencari kekayaan untuk memenuhi kebutuhan. Beberapa penulis telah mencoba menggambarkan konsep social reporting dalam akuntansi Islam. “

Menurut Haniffa (2002), tujuan dari social reporting dalam perspektif Islam adalah sebagai berikut:

- Menunjukkan akuntabilitas kepada Tuhan dan masyarakat.

- Meningkatkan transparansi kegiatan bisnis dengan menyajikan informasi yang relevan dengan memperhatikan kebutuhan spiritual investor Muslim dalam pengambilan keputusan.

Dalam konteks tersebut, maka social reporting Islam harus mampu mengungkapkan beberapa informasi yang dibutuhkan pembaca laporan sehingga dapat menjawab,segala pertanyaan yang berkaitan dengan keyakinan dan hukum Islam. (TAZKIA, 2010:8 Erna Agustin Rozian Sofie,, 2010:62) Haniffa (2002) memberikan prinsip etika dan isi dari social reporting sebagai berikut:

"Menurut Haniffa (2002), format akuntansi Islam harus mencakup aspek sosial ekonomi dan menjamin terciptanya keadilan sosial dan mencari 
kesejahteraan dunia dan akhirat. Bukan hanya berdimensi dunia apalagi hanya mancari laba pihak tertentu saja.

"Ia menjelaskan bahwa laporan keuangan harus menggambarkan aspek etis yang menjelaskan akuntabilitas terhadap Tuhan dan manusia serta transparansi mengenai seluruh kegiatan perusahaan yang diperlukan oleh manusia untuk memastikan semuanya sesuai dengan ketentuan Allah SWT." Erna Agustin Rozian Sofie,, 2010:62)

Aspek akuntabilitas dirinci informasi yang dibutuhkan (Haniffa, 2002) yaitu:

- Amanah

- Memenuhi kewajiban kepada Allah dan manusia

- Mengejar laba sesuai syari’ah

- Mencapai tujuan perusahaan

- Adil kepada karyawan dan masyarakat

- Meyakinkan bahwa kegiatan perusahaan tidak merusak lingkungan

- Menganggap tugas adalah berdimensi dari ibadah

$$
\text { Hal-hal yang diungkapkan }
$$
penyusun standar dan badan pengawas seperti SEC atau BAPEPAM mengeluarkan ketentuan tentang apa yang harus diungkapkan. Struktur pengaturan di Indonesia kurang lebih sama dengan yang diterapkan di
Amerika, yaitu struktur pengaturanganda (IAI dan BAPEPAM). Dalam hal ini BAPEPAM lebih berkepentingan dengan tingkat pengungkapan dan apa yang harus diungkapkan terutama untuk kepentingan pendaftaran publik dan penawaran publik perdana.

Sementara itu, IAI lebih berfokus pada bagaimana mengungkapkan atau format pengungkapan terutama dalam pelaporan keuangan eksternal. Ketentuan IAI, yakni Standar Akuntansi Keuangan (SAK) dapat diberlakukan pula untuk perusahaan swasta (non publik). Beberapa peraturan BAPEPAM yang mengatur pengungkapan: (Tazkia Erna Agustin Roziani, Sofie, 2010:58)

Cara Pengungkapan Secara garis besar, disclosure mengikuti pedoman berikut:

- Laporan keuangan, terdiri dari tiga laporan utama yakni laporan neraca, laba rugi, dan laporan perubahan posisi keuangan. Disclosure dalam laporan keuangan bisa dalam bentuk laporan laba rugi, laporan perubahan posisi keuangan juga termasuk rincian dan tabel-tabel untuk menjelaskan angka-angka yang terdapat dalam laporan keuangan 
yang disajikan secara komparatif dengan periode lalu.

- Catatan kaki. Catatan kaki merupakan bagian yang tidak terpisahkan dari laporan keuangan sehingga dalam catatan kaki ini sering disajikan catatancatatan yangberhubungan dengan item-item neraca dan laba rugi.

- Data statistik. Data-data ini disusun dan diolah dari angka-angka yang terdapat dalam laporan keuangan dan seringkali disajikan secara terpisah di dalam laporan tambahan.

- Laporan auditor. Laporan ini merupakan media yang paling sesuai untuk mengungkapkan penyimpangan dan akibat penyimpangan penerapan prinsip akuntansi dari prinsip akuntansi yang berterima umum, perubahan prinsip akuntansi dan akibatnya, dan perbedaan pendapat antara auditor dan manajemen perusahaan yang diaudit.

"Laporan keuangan merupakan hasil akhir dari suatu proses akuntansi. Agar informasi keuangan yang disajikan bermanfaat bagi para pemakai, maka proses penyajiannya harus berdasarkan pada standar akuntansi yang berlaku. Perumusan standar akutansi memerlukan acuan teoritikal yang dapat diterima umum, sehingga standar akuntansi yang diterapkan dapat digunakan untuk mengevaluasi praktik akuntansi yang berlangsung. (TAZKIA Erna Agustin Roziani, Sofie,2010:59)”

Acuan teoritikal ini disebut kerangka konseptual penyusunan laporan keuangan. Oleh karena akuntansi konvensional yang dikenal saat ini diilhami dan berkembang berdasarkan tata nilai yang ada dalam masyarakat barat, maka kerangka konseptual yang dipakai sebagai dasar pembuatan dan pengambangan standar akuntansi berpihak kepada kelompok kepentingan tertentu.

Fenomena kegagalan akuntansi konvensional dalam analisis faktorfaktor yang memenuhi tuntutan masyarakat akan informasi keuangan yang benar, jujur dan adil,meningkatkan kesadaran di kalangan intelektual muslim akan perlunya pengetahuan akuntansi yang islami.

Perumusan kembali kerangka konseptual pelaporan keuangan dengan mendasarkan pada prinsip kebenaran, kejujuran dan keadilan menjadi sangat mendesak untuk dilakukan. Mengingat akuntansi syariah sesuai dengan fitrah (kecenderungan) manusia yang 
menghendaki terwujudnya kehidupan bermasyarakat yang menjunjung tinggi etika dan tanggung jawab sosial.

Di sinilah perbedaan antara paham akuntansi konvensional dengan akuntansi syariah. Paham akuntansi konvensional hanya mementingkan kaum pemilik modal (kapitalis), sedangkan akuntansi syariah bukan hanya mementingkan manusia saja, tetapi juga seluruh makhluk di alam semesta ini.

\section{Syariah Enterprise Theory dan Islamic} Social Reporting (ISR)

Konsep enterprise theory lebih menyerupai stakeholders theory, karena kedua teori ini mengakui keberadaan stakeholder sebagai pemegang kepentingan dan tanggung jawab perusahaan. Kedua konsep ini lebih sarat dengan nilai-nilai kapitalisme.

Selain itu, dalam teori tersebut mencakup nilai-nilai syariah (keadilan, rahmatan lil alamin, dan maslahah), karena dalam konsep enterprise theory dan stakeholders theory dijelaskan bahwa kesejahteraan tidak hanya diperuntukkan bagi pemilik modal, melainkan bagi kepentingan semua stakeholder / manusia.
Menurut para ahli, enterprise theory ini lebih tepat untuk suatu sistem ekonomi yang mendasarkan diri pada nilai-nilai syariah, karena Menekankan akuntabilitas yang lebih luas (Triyuwono,2007: 4),

Hal ini sebagaimana dinyatakan Syariah Enterprise Theory merupakan enterprise theory yang telah diinternalisasi dengan nilai-nilai Islam guna menghasilkan teori yang transendental dan lebih humanis. Enterprise theory, seperti telah dibahas oleh (Triyuwono, 2007: 4) :

"Merupakan teori yang mengakui adanya pertanggungjawaban tidak hanya kepada pemilik perusahaan saja melainkan kepada kelompok stakeholders yang lebih luas. Enterprise theory mampu mewadahi kemajemukan masyarakat (stakeholders), hal yang tidak mampu dilakukan oleh proprietary theory dan entity theory. Hal ini karena konsep enterprise theory menunjukkan bahwa kekuasaan ekonomi tidak lagi berada di satu tangan (shareholders), melainkan berada pada banyak tangan, yaitu stakeholders.

Syariah Enterprise Theory (SET) tidak hanya peduli pada kepentingan individu (dalam hal ini pemegang saham), tetapi juga pihakpihak lainnya. 
Oleh karena itu, SET memiliki kepedulian yang besar pada stakeholders yang luas. Menurut SET, stakeholders meliputi Allah, manusia, dan alam.(Triyuwono (2007:4-5)

$$
\text { Menurut (Meutia,2010: }
$$

menyatakan bahwa teori yang paling tepat untuk mengungkapkan tanggung jawab sosial perusahaan, dalam hal ini bank syariah, adalah Syariah Enterprise Theory (SET).

Menurut Baydoun \& Willet (1997) menyatakan :

“Islamic Social Reporting (ISR) Sejalan dengan makin meningkatnya pelaksanaan CSR dalam konteks Islam, maka makin meningkat pula keinginan untuk membuat pelaporan sosial yang bersifat syariah (Islamic Social Reporting atau ISR). Ada dua hal yang harus diungkapkan dalam perspektif Islam, yaitu: pengungkapan penuh (full disclosure) dan akuntabilitas sosial (social accountability). Konsep akuntabilitas sosial terkait dengan prinsip pengungkapan penuh dengan tujuan untuk memenuhi kebutuhan publik akan suatu informasi. Dalam konteks Islam, masyarakat mempunyai hak untuk mengetahui berbagai informasi mengenai aktivitas organisasi. Hal ini dilakukan untuk melihat apakah perusahaan tetap melakukan kegiatannya sesuai syariah dan mencapai tujuan yang telah ditetapkan “

Sampai saat ini kajian mengenai CSR dari pandangan Islam untuk diaplikasikan pada perbankan Islam hampir jarang ditemukan. Ada beberapa kajian yang telah dibuat, seperti oleh Asyraf Wajdi Dusuki dan Humayon Dar. Dalam kajian yang dibuat oleh Asyraf dan Humayon dalam M Yasir Yusuf (2010) menjelaskan :

"Hanya memaparkan pandangan berbagai stakeholder bank Islam mengenai CSR dan sejauh mana pandangan mereka terhadap CSR bank Islam boleh mempengaruhi pilihan mereka terhadap bank Islam. Kesimpulan kajian adalah dari tujuh stakeholder yang dikaji mempunyai persepsi yang positif terhadap CSR bank Islam di Malaysia dan CSR menjadi salah satu variable yang penting bagi stakeholder dalam penentu pilihan terhadap bank Islam di Malaysia."

Yang luput dari kajian Asyraf dan Humayon yaitu mereka tidak membuat konsep dan bentuk CSR dalam pandangan Islam dan kriteria-kriteria CSR yang sepatunya wujud dalam perbankan Islam. Padahal bentuk dan kriteria CSR dalam Islam sudah barang 
tentu mempunyai perbedaan dengan bentuk $C S R$ di dunia barat. Bentuk dan kriteria ini penting untuk dikaji sehingga perbankan Islam boleh menjalankan program CSR secara tepat sasaran dalam memberdayakan ekonomi masyarakat.

Menurut Harahap (2003) dalam Irman Firmansyah (2010) :

"Pencapaian al-falaah merupakan orientasi utama dari akuntansi Islam. Dengan demikian, tujuan akuntansi Islam tidak hanya terbatas pada kepentingan ekonomi, tetapi juga kepentingan non ekonomi. Akuntansi Islam tidak akan hanya mengukur nilai moneter dan tidak pula hanya yang bersifat resiprocal transaction suatu organisasi tetapi juga nilai non ekonomi serta non resiprocal transaction "

Penelitian ini bertemakan mengenai pengungkapan tanggung jawab social perusahaan khususnya di lihat dari sudut pandang syariah di Indonesia menggunakan media yang berbeda - beda. menjadi indikasi kurangnya transparansi pengungkapan berdasarkan nilai - nilai Islam, padahal kenyataannya konsep akuntabilitas dalam Islam terkait dengan prinsip pengungkapan penuh (full disclosure).

Dan Coorporate social responsibility merupakan upaya perusahaan untuk meningkatkan kualitas hidup stakeholder. Stakeholder meliputi pernyataan yang melindungi kepentingan sosial selain itu (Zubairu,2012) menunjukkan bahwa praktik pengungkapan $C S R$ pada bank syariah masih minim, padahal bank tersebut mengklaim dirinya sebagai institusi yang beroperasi sesuai dengan prinsip Islam.

\section{Metode Penelitian}

Penelitian ini merupakan berusaha untuk melakukan deskriptif akan pengungkapan akuntansi pertanggungjawaban sosial (Corporate social Responcibility Disclosure) sebagai pengungkapan sukarela atas kebutuhan informasi stakeholder studi pada bank Mandiri syariah dan Bukopin syariah.

Adapun untuk mengetahui bahwa sejauh mana indeks publisitas pengungkapan informasi CSR yang disajikan pada bank Mandiri syariah dan bank Bukopin syariah sesuai dengan konsep syariah.

Pada penelitian ini peneliti melakukan penelitian kualitatif dengan pendekatan fenomenologi agar tujuan penelitian tercapai. Dengan pendekatan fenomenologi peneliti dapat mengamati 
secara langsung realitas yang terjadi, sehingga dapat memperoleh informasi yang mendalam.

Metode purposive sampling dalam penelitian ini telah memilih narasumber yang bisa memahami tentang laporan CSR berlandaskan syariah dengan berbagai peran dan keterlibatannya sebagai kebutuhan penelitian yang dilakukan.

Informan yang dipillih oleh peneliti dalam penelitian ini sebagai narasumber yang dianggap sesuai dengan kebutuhan yang dibutuhkan peneliti yaitu seorang manajer akunting / yang mengerti akan laporan keuangan dan laporan $C S R$.

Sedangkan data sekunder yaitu data yang diperoleh dari dokumentasi arsip perusahaan. Dalam hal ini peneliti melakukan pengambilan data dokumentasi arsip, data sejarah perusahaan, struktur perusahaan, Sustainability Report (Laporan Keberlanjutan) dan Annual Report (Laporan Keuangan) bank Mandiri Syariah. Dari Sustainability Report dan Annual Report diketahui bahwa sejauh mana indeks publisitas pengungkapan informasi CSR yang disajikan oleh bank Mandiri syariah dan Bukopin syariah
Setelah data ditentukan, selanjutnya teknik pengumpulan data supaya mendapatkan data yang sesuai dengan tujuan dari penelitian dan memenuhi standar yang diinginkan peneliti.

Observasi ini dilakukan dengan cara melakukan pengamatan langsung ke perusahaan. Dalam penelitian ini peneliti melakukan observasi ke bank Mandiri Syariah dan bank Bukopin syariah yang merupakan subjek penelitian dengan tujuan untuk mengetahui serta mendapatkan gambaran tentang perlakuan akuntansi pengungkapan CSR dengan berbasis syariah dilihat dari Sustainability Report (Laporan Keberlanjutan) dan Annual Report (Laporan Keuangan) dalam pelaksanaannya melalui program program CSR yang dilaksanakan oleh bank Mandiri syariah tersebut telah sesuai dengan konsep syariah

Dalam penelitian ini peneliti melakukan wawancara dengan pihak yang berpengaruh dengan objek yang diteliti, yang dilakukan terhadap pejabat atau pihak-pihak yang terpercaya dalam perusahaan. Pihak yang dimaksudkan adalah kepala bagian akuntansi / bagian yang mengerti akan Sustainability Report (Laporan Keberlanjutan) dan Annual Report (Laporan Keuangan) 
agar pertanyaan yang diberikan mendapatkan penjelasan mengenai perlakuan CSR di bank Mandiri syariah dan Bukopin syariah lebih tersampaikan dengan jelas seperti akan macam program, konsep, sumber dana, dll.

Dokumen ini bisa berbentuk tulisan, atau gambar. Dokumen yang diperlukan oleh peneliti adalah dokumen yang berisi bahan-bahan informasi yang dihasilkan dari bank Mandiri syariah berupa dokumen arsip seperti Sustainability Report (Laporan Keberlanjutan) dan Annual Report (Laporan Keuangan), foto bergambar disaat pelaksanaan CSR maupun saat wawancara

Dalam penelitian kualitatif instrument utamanya pada penelitian ini adalah peneliti sendiri. Karena pada awalnya penelitian kuallitatif belum jelas dan pasti. Karena pada dasarnya peneliti harus berperan dalam melakukan pengamatan yang lebih mendalam pada objek penelitian.

Segala sesuatu masih perlu dikembangkan sepanjang penelitian itu dalam keadaan yang tidak jelas dan pasti itu tidak ada pilihan lain dan hanya peneliti itu sendiri sebagai alat satusatunya yang dapat mencapainya.
Maka dari itu peneliti telah melakukan pengamatan langsung ke lapangan dan berinteraksi dengan orangorang yang berkaitan langsung dengan tujuan dari penelitian ini. Pada saat dilapangan peneliti melakukan observasi pengumpulan data baik primer ataupun sekunder dengan memperbanyak wawancara dengan yang memahami CSR berlandaskan syariah, juga mendokumentasikan yang berhubungan dengan yang diteliti.

Dalam penelitian kualitatif, data yang diperoleh dari berbagai sumber dan teknik pengumpulan data. Maka dari itu memerlukan analisis data kualitatif yang disebut analisis data Bogdan \& Biklen (dalam buku ULexy J moleong, 2011:248), mengungkapkan bahwa :

"Analisis data kualitatif adalah upaya yang dilakukan dengan jalan bekerja dengan data, mengorganisasikan data, memilah-milahnya menjadi satuan yang dapat dikelola, mensistematiskannya, mencari dan menemukan pola, menentukan apa yang penting dan apa yang dipelajari dan memutuskan apa yang dapat diceritakan kepada orang lain."

Kesimpulan sementara yang dirumuskan masih terus diverifikasi berulang-ulang dan berharap sehingga 
menjadi kesimpulan akhir. Setelah selesai dilapangan

Pada saat analisis dilapangan telah selesai maka peneliti melakukan tahap evaluasi dan pelaporan, pada tahapan ini peneliti melakukan konsultasi dan bimbingan dengan dosen yang telah ditentukan

\section{Hasil dan Diskusi}

Kebijakan Akuntansi Dan Standar

\section{Bank Syariah}

Laporan posisi keuangan, laporan laba rugi dan penghasilan komprehensif, laporan arus kas dan laporan perubahan ekuitas merupakan laporan keuangan yang mencerminkan kegiatan komersial Bank sesuai dengan prinsip syariah.

Laporan arus kas disusun dengan menggunakan metode langsung dengan mengelompokkan arus kas dalam aktivitas operasi, investasi dan pendanaan. Untuk tujuan laporan arus kas, kas dan setara kas terdiri dari kas, giro pada Bank Indonesia, giropada bank lain dan penempatan pada Bank Indonesia dan bank lain yang jatuh tempo dalam periode 3 (tiga) bulan dari tanggal akuisisi.

Laporan rekonsiliasi pendapatan dan bagi hasil merupakan rekonsiliasi antara pendapatan bank syariah yang menggunakan dasar akrual (accrual basis) dengan pendapatan yang dibagihasilkan kepada pemilik dana yang menggunakan dasar kas (cash basis).

Laporan sumber dan penyaluran zakat merupakan laporan yang menunjukkan sumber dana dan penyaluran dalam jangka waktu tertentu serta dana zakat yang belum disalurkan pada tanggal tertentu.

Zakat adalah sebagian dari harta yang wajib dikeluarkan oleh muzakki (pembayar zakat) untuk diserahkan kepada mustahiq (penerima zakat). Sumber dana zakat, infaq dan shadaqah berasal dari Bank dan pihak lain yang diterima Bank untuk disalurkan kepada pihak yang berhak sesuai dengan prinsip syariah.

Bank tidak membuat laporan sumber penggunaan dana zakat, infaq dan shadaqah karena Bank tidak secara langsung menjalankan fungsi penyaluran dana zakat infaq dan shadaqah.

Laporan sumber dan penggunaan dana kebajikan merupakan laporan yang menunjukkan sumber dan penggunaan dana kebajikan selama jangka waktu tertentu dan saldo dana kebajikan pada tanggal tertentu. Mata uang pelaporan yang digunakan dalam laporan keuangan 
adalah mata uang Rupiah ( $R p)$ yang juga merupakan mata uang fungsional Bank.

Dampak Penerapan standar akuntansi barupada saat penerbitan laporan keuangan, Bank masih mempelajari dampak yang mungkin timbul dari penerapan standar baru dan amendemen tersebut serta pengaruhnya pada laporan keuangan Bank. Adanya sedikit sekali perbedaan dalam penggunaan praturan psak antara masing masing bank syariah

\section{Pengungkapan}

informasi

\section{kemasyarakatan}

Terkait PengemBangan social kemasyarakatan kebijakan CSR Pengembangan social kemasyarakatan Pelaksanaan program CSR pengembangan sosial kemasyarakan mengacu pada Perjanjian Kerja Sama (PKS) BSM dan Lembaga amil Zakat nasional (LAZNAS) BSM no. 30 agustus 2016: no. 18/586-PKS/Dir; 15/007PKS/LAZNAS tentang Penyaluran Dana Zakat, Dana infaq dan Dana Sosial.

Dalam hal penghimpunan dana, secara periodik

BSM menyalurkan dana Zakat (dari keuntungan perusahaan, nasabah, pegawai), dana infaq (sumbangan sukarela dari nasabah, pegawai dan masyarakat) dan dana Program (dari pendapatan non halal BSM) melalui LaZnaS BSM

\section{Pengungkapan Informasi}

\section{Ketenagakerjaan}

CSR terkait ketenagakerJaan,kesehatan dan keselamatan kerja kebijakan kesehatan Pegawai Kepedulian Bank terhadap layanan kesehatan pegawai dapat dilihat dari piilihan paket kesehatan yang disediakan.

Bentuk komitmen BSM terkait ketenagakerjaan dibuktikan dengan pemenuhan kewajiban perusahaan dalam bentuk manfaat bagi pegawai yang diakui sebagai beban operasional perusahaan sebagaimana dalam laporan keuangan Bank.

Begitu pula Bank Bukopin Syariah. Aspek ketenagakerjaan, kesehatan, dan keselamatan kerja merupakan bagian dari penyelenggaraan CSR. Untuk itu, Perseroan berupaya mewujudkannya melalui pelaksanaan program yang disesuaikan dengan kebijakan dan regulasi yang berlaku.

Pada tahun 2016, Perseroan telah menerapkan kebijakan pemberian bantuan pendidikan kepada karyawan, 
bonus/ tunjangan prestasi kerja kepada karyawan, Tunjangan Hari raya Idul Fitri 1437 H diberikan kepada seluruh karyawan dengan status tetap/kontrak/harian, pemberian Tunjangan Jaminan Pensiun pada BPJS Ketenagakerjaan bagi karyawan, dan pemberian apresiasi akhir tahun pada karyawan. Selain itu, selama tahun 2016 karyawan telah dilindungi asuransi adira dinamika Medicillin, BPJS Kesehatan, dan BPJS Ketenagakerjaan, serta bantuan-bantuan perusahaan lainnya yang bersifat insidental.

\section{Pengungkapan informasi Lingkungan hidup}

Penggunaan material dan energi yang ramah ingkungan dan dapat didaur ulang BSM mempunyai kebijakan berdasarkan pada prinsip efektivitas dan efisiensi dalam penggunaan material dan energi.

Dalam menunjang operasional bank, BSM menggunakan material ramah lingkungan seperti kertas, tinta dan lain-lain. Terkait dengan energi, BSM menggunakan kendaraan LcGc (low cost green car) dengan bahan bakar yang disediakan oleh pemerintah.

BSM memandang daur ulang material adalah salah satu strategi pengelolaan sampah padat sesuai prinsip 3r (Reuse, Reduce, and Recycle). Prinsip ini memastikan bahwa terjadi pemanfaatan sisa material dalam bentuk barang baru yang memiliki manfaat. Sebagai contoh BSM memanfaatkan kembali kertas bekas yang tidak terpakai untuk mencetak dokumen-dokumen internal BSM.

Disamping hal tersebut, manajemen telah menerapkan penggunaan kertas daur ulang atau kertas ramah lingkungan dalam pembuatan Laporan Tahunan sistem Pengolahan limbah Perusahaan BSM secara khusus tidak memiliki sistem pengelolaan limbah perusahaan. hal ini terkait dengan bisnis utama perusahaan yang bergerak dalam bidang perbankan. namun demikian,upaya untuk berkontribusi dalam menerapkan prinsip 3r (Reuse,Reduce, and Recycle) terus dilakukan oleh Bank.Pertimbangan aspek lingkungan dalam pemberian kredit/Pembiayaan kepada nasabah

\section{Pengungkapan Informasi Konsumen} CSR terkait konsumen target/rencana kegiatan 2016 Terkait dengan CSR Konsumen, BSM memiliki target untuk menyelesaikan berbagai pengaduan nasabah yang masuk ke 
BSM. hal ini dimaksudkan agar nasabah memiliki tingkat kepuasan dan kepercayaan yang tinggi terhadap BSM. Pengelola Saat ini pengaduan nasabah yang diterima oleh BSM dikelola oleh unit Kerja customer care Management yang berada di culture \& customer care Group.

\section{Pengungkapan $\quad C S R \quad$ terkait stakeholder}

Sejalan dengan misi perusahaan yang berkaitan dengantanggung jawab sosial, dengan tujuan:

1. Mewujudkan hubungan yang harmonis antara perusahaan dan masyarakat

2. Membantu tumbuh dan berkembangnya usaha kecil dan koperasi yang mandiri, tangguh, dan berdaya saing, serta mampu meningkatkan penyerapan tenaga kerja melalui pengelolaan yang profesional.

3. Mengembangkan pola pembinaan usaha kecil dan koperasi,yang berpotensi memberi hubungan timbal balik jangka panjang dengan bisnis Perseroan melalui penyaluran dana kemitraan dan pembinaan berkesinambungan, dengan mengedepankan aspek pemerataan, kemandirian, profesional, dan etika.

4. Partisipasi pada program pelestarian lingkungan hidup dan membantu meningkatkan kualitas hidup masyarakat yang meliputi bidang pendidikan, kesehatan, dan kesejahteraan.

5. Turut mendukung peningkatan kualitas pendidikan, kesehatan, kehidupan beragama, dan sarana umum lainnya. Kebijakan CSR dilakukan melalui pendekatan tripple bottom lines yang meliputi kinerja ekonomi (economic indicators), kinerja lingkungan (environmental indicators), dan kinerja sosial (social indicators).

Melalui kebijakan tersebut BSM berharap tidak hanya bermanfaat bagi para pemegang saham (shareholders), tetapi juga kepada pemangku kepentingan (stakeholders) yang lebih luas yaitu masyarakat dan lingkungan.

Dengan kata lain, berusaha untuk memaksimalkan laba perusahaan (profit) selaras dengan tujuan untuk memberikan kemanfaatan bagi masyarakat (people), dan lingkungan (planet). meyakini bahwa dengan pendekatan yang menyeluruh ini akan mendukung tercapainya tujuan pembangunan yang 
berkelanjutan

(sustainable

development), yaitu kegiatan pembangunan yang dilakukan untuk memenuhi kebutuhan generasi sekarang tanpa mengorbankan kepentingan generasi mendatang.

Untuk informasi stakeholder tlah sesuai GRI G4, Penetapan konten laporan ini didasarkan pada 4 (empat) prinsip, yakni: Stakeholders inclusiveness (Pelibatan Pemangku Kepentingan); Materiality (Materialitas) dan Sustainability context (Konteks Keberlanjutan) dan Completeness (Lengkap).

\section{Simpulan}

Berdasarkan hasil penelitian dan pembahasan yang telah diuraikan pada bab sebelumnya, maka dapat ditarik kesimpulan:

Laporan Keuangan yang disusun oleh Bank Syariah Mandiri dan Bank Syariah Bukopin telah mengikuti Undang undang, pedoman, dan peraturan kurang lebih telah memberi standar atas pelaksanaan dan pengungkapan Corporate Social Responsibility pada perusahaan. Namun, praktik Corporate Social Responsibility di Indonesia masih bersifat sukarela, hanya perusahaan yang berkaitan langsung dengan sumber daya alam, maka perusahaan tersebut wajib untuk melaksanakan Corporate Social Responsibility.

Kegiatan pelaksanaan Bank Syariah Mandiri dan Bank Syariah Bukopin Banyak mengadakan berbagai macam program sosial dari masing masing bank syariah dari mulai kemasyarakatan,

ketenagakerjaan,lingkungan dan untuk kepentingan konsumen sangat membantu sekali juga menimbulkan citra yang baik bagi pihak bank tersendiri dengan menggunakan perangkat bank yaitu sekertaris perusahaan dalam pengungkapan Corporate Social Responsibility menjadi jembatan pengsosialisasian komunikasi kepada stakeholder.

Pengungkapan CSR pada Bank Syariah Mandiri dan Bank Syariah Bukopin Masih menggunakan dana non halal pada sumber dana CSR yang seharusnya dipisahkan Pengungkapan dan pelaksanaan - Corporate Social Responsibility diwajibkan kepada perusahaan yang berkaitan langsung dengan sumberdaya alam dan belum menyajikan laporan tanggung jawab sosial pada program ketenagakerjaan dan konsumen dengan rincian alokasi 
dan bukan hanya hasil deskripsi kegiatan saja.

Strategi Bank Syariah Mandiri dan Bank Syariah Bukopin sama yaitu Dengan menjadikan kinerja lebih baik / dimata para masyarakat khususnya nasabah perusahaan fositif dan bertambah banyak peminat menggunakan jasa perbankan di bank tersebut

\section{Daftar Pusataka}

Agustina, S. 2012 ." Pengaruh Profitabilitas Dan Pengungkapan Corporate Social Responsibility Terhadap Nilai Perusahaan . jurnal. Fakultas ekonomi negeri Padang. Padang

https://google.com/\#q=jurnal+agustina $\% 2 \mathrm{C}+\mathrm{s}+2012=$ pengaruh + profitabi litas+terhadap+nilai+perusahaan.

Ali syukron, 2015. “Tanggung Jawab

Sosial dan Kinerja Keuangan Umum Syariah Di Bank Indonesia”, skripsi, Sekolah tinggi Agama islam Darul ulum Banyuwangi, economic jurnal ekonomi dan hukum islam vol5 no 2 issn 2088- 6365 e-issn 24775576

Anggraini, Vita, 2007. “ Pengaruh Tingkat Disclosure dan Nilai
Pasar Ekuitas Terhadap Biaya Ekuitas", Skripsi, Universitas Kristen Petra, Surabaya

Anggraeni Yunita (2010) . "Biaya Sosial Sebagai Bagian Corporate Social Responsibility Dalam Sudut Pandang Akuntansi:

Baydoun, N. \& Willet, R. 1997. Islamic Ethical Issues in the Presentation of Financial Information. Accounting, Commerce and Finance: The Islamic Perspective Journal, 1(1).

Chariri, A.,\& Ghazali, I. (2007). Teori Akuntansi, Semarang: Badan Penerbit UNDIP Chapra,m umer,. 2007 .The islamic vision of development in the light of maqasid al shariah. Jedah: islamic research and training institute islamic development bank

Chapra, M Umer.. The Islamic Vision of Development in the Light of Maqasid AlShari"ah. Jeddah: Islamic Research and Training Institute Islamic Development Bank. 2007

Dwi hartanti , Soraya Fitria (2015) islam dan tanggung jawab sosial : studi perbandingan pengungkapan berdasarkan global reporting 
initiative indeks dan islamic social reporting fakultas ekonomi universitas indonesia

Deegan, C. and Gordon B. A Study of the Environmental Disclosure Practices of Australian Corporations. Accounting and Business Researclt. Vol. 26, No. 3, (Summer), pp. 187-99, (1996)

Dariyani (2010),Pengungkapan Akuntansi...JEAM vol IX no 1/10 ISSN: 1412-5366 fakultas ekonomi

DR MARIA R Nindita Radyanti-media indonesia http//www.mmcsrtrisakti.com/en/ pages/news_read/146/csr-dan mitigasi-resiko-maria-r-ninditaradyanti-media-indonesia

Dita Andraeny (2014) .Pengungkapan Tanggung Jawab Sosial Perusahaan: Studi Empiris Pada Bank Syariah Di Indonesia Fakultas Ekonomi Dan Bisnis Islam Iain Surakarta Jl. Pandawa, Pucangan, Kartasura, Surakarta Jurnal EKA CIDA Vol 1. No. 1 Maret 2016 55

ISSN: 2503-3565 e-ISSN: 25033689

Farook, s and Lanis, R. (2005) banking on islam ? determinans of coporate sosial responsibility disclosure. The 6 th international conference on islamic and finance.Jakarta

Feranande (2012). Pengaruh total arus kas laba kotor dan ukuran perusahaan terhadap return saham perusahaan real estate and property yang terdaftar di bursa efek indonesia. Universitas Tarumanegara.Jakarta/

Fitria soraya dan Dwi Hartanti (2010) Islam Dan Tanggung Jawab Sosial: Studi Perbandingan Pengungkapan Berdasarkan Global Reporting Indeks.simposium nasional akuntansi 13 purwokerto.

Firmansyah, Irman (2010). ISR Sebagai Proksi Pengungkapan CSR Bank Muamalat Indonesia Dan Bank Syariah Mandiri. Tasikmalaya : Universitas Siliwangi Tasikmalaya Freeman, R. E., (1984). Strategic Management: A Stakeholder Approach, , Boston: Pitman Publishing

Grimble, r and wellard, k, 1996. Stakeholder methodologies in natural resource management: A review of principles. Contexts, exsperiences, and opportunities. Paper presented at the ODA NRSP 
Socioeconomic methodologies workshop, 29-30 Apr, 1996, London, UK

Gamerschlag et 1 (2011). “ determinansts voluntary csr disclosure: empirical evidence from germany “. Review of managerial science 5 no 2-3, pp 233262

Harmain, (2016) "DPR ngotot wajibkan csr bagi semua perusahaan halaman

http://m.kontan.co.id/news/dpr-ngototwajibkan-csr-bagi-semuaperusahaan

Hasibuan, m ,(2001). “ pengaruh karakteristik perusahaan terhadap pengungkapan social (social disclosure) dalam laporan tahunan 76 emiten diBEJ dan BES ". tesis S2 magister akuntansi universitas diponegoro. semarang

Lailatul Khasanah (2016) Analisis Perbandingan Pengungkapan Tanggung Jawab Sosial (Studi Kasus Pada Bank Umum Syariah Di Indonesia) Skripsi Fakultas Ekonomika Dan Bisnis Universitas Diponegoro ,Semarang

Mulyanita sugesty 2009. "Pengaruh Biaya Tanggung Jawab Sosial Perusahaan terhadap kinerja
Perusahaan Perbangkan, Jurusan akuntansi Fakultas Ekonomi , universitas Lampung

Meutia ,intern. 2010. Shariah enterprise theory sebagai dasar pengungkapan tanggung jawab sosial untuk bank Syariah. Disertasi. Malang Program pascasarjana universitas Brawijaya Napier (2007), pada "Pengertian Akuntansi menurut para ahli, Akuntansi Online " halaman url : //www.belajarakuntansionline.co $\mathrm{m} /$ pengertian-akuntansi-syariahmenurut-para-ahli /

Murni, Siti Aisah, 2004. Pengaruh Luas Pengungkapan Sukarela Dan Asimetri Informasi terhadap cost of capital pada perusahaan publik di indonesia. Jurnal Riset Akuntansi di indonesia, Vol 7 no 2

Pasal 74 UU No. 40 Tahun 2007 tetang Perseroan Terbatas arsip negara

Patten, D.M., "Intra-industry Environmental Disclosures in Response to the Alaskan Oil Spill: A Note on Legitimacy Theory". Accounting, Organizations and Society, Vol. 15, No. 5, pp. 471-75, (1992). 
VOL. 2 NO. 2 JANUARI - JUNI 2018 e-ISSN: 2621-5306

VOL. III NO. 1 JANUARI - JUNI 2018 p-ISSN: 2541-5255

Rolia Wahasusmiah (2015)

.Pengungkapan Tanggung Jawab

Sosial Secara Syariah Terhadap

Kinerja Keuangan Dan Kinerja

Lingkungan skipsi Universitas

Bina Darma.

Ririn Irmadariyani

(2010)

Pengungkapan

Akuntansi

Pertanggungjawaban

Sosial(Corporate

Social

Responsibility

Disclosure)sebagaiPengungkapan

Sukarela Kebutuhan Informasi

Stakeholder pada Official Website

Perusahaan (Studi Pada Pt.

Indosat Tbk)

Sairally, Salma. 2005. Evaluating the

'Social Responsibility' of Islamic

Finance: Learning From the

Experiences of Socially

Responsible Investment Funds.

The 6th International Confrence

on Islamic Economic and Finance.

Supomo, sita (2004) Corporate Social Responsibility Csr Dalam Prinsip Gcg” Dalam Republika 20 Oktober

Sembiring. Karakteristik Perusahaan Dan Pengungkapan Tanggung Jawab Sosial (Studi Empiris Pada Perusahaan Tercatat Di BEJ).
Proceeding seminar nasional, surakarta

Syuhada Mansur (2012) .Pelaporan Corporate Social Responsibility Perbankan Syariah Dalam Perspektif Syariah Enterprise Theory (Studi Kasus Pada Laporan Tahunan Pt Bank Syariah Mandiri) skripsi Fakultas Ekonomi Dan Bisnis Universitas Hasanuddin economic :jurnal ekonomi hukum islam vol.2 no. 2 ISSN 2088-6365

TAZKIA Islamic Finance \& Business Review Vol. 5 No.1 Januari - Juli 2010

Triyuwono, Iwan. 2000. Organisasi dan Akuntansi Syariah. Yogyakarta: LkiS

Triyuwono, Iwan. "Mengangkat "sing liyan" untuk Formulasi Nilai Tambah Syari'ah".Simposium Nasional Akuntansi X Unhas, 2628 Juli 2007. 1-21.

Wibisono, Yusuf.(2007) Membedah Konsep dan Aplikasi CSR. Gresik: Fascho Publishing,

Yusuf, Yasir. "Aplikasi CSR pada Bank Syariah: Suatu Pendekatan Maslahah dan Maqasid syariah. EKSIBISI, Vol 4, No 2, (Juni 2010) 
Yuningsih (2004) “ pengaruh karakteristik perusahaan terhadap praktek pengunggkapan tanggung jawab sosial dan lingkungan perusahaan publik". balance, vol 1 no 2, 2004

Zappi, Gianna. "Corporate Responsibility in the Italian banking industry: Creating Value Through Listening to Stakeholders". Corporate Governance, Vol. 7 Issue: 4, pp.471 - 475, (2007) 